\title{
Trait-mediated ecosystem impacts: how morphology and size affect pumping rates of the Caribbean giant barrel sponge
}

\author{
Steven E. McMurray, Joseph R. Pawlik, Christopher M. Finelli* \\ Department of Biology and Marine Biology, University of North Carolina Wilmington, Wilmington, North Carolina \\ 28403-5919, USA
}

\begin{abstract}
Sponges are a dominant component of Caribbean coral reef suspension-feeding communities. Understanding how pumping rates are affected by sponge size and morphology, as well as the environment, is fundamental to understanding the ecological interactions that are mediated by sponge filtration. In a comprehensive in situ investigation of sponge pumping, the excurrent seawater velocities of 274 specimens of the largest Caribbean species, the giant barrel sponge Xestospongia muta, were measured at sites in the Bahamas and Florida Keys to investigate (1) the relationship between excurrent velocity distributions and sponge morphology, (2) the scaling relationship between pumping and sponge size, and (3) temporal variation of pumping and sensitivity to environmental changes. Excurrent velocity distributions across the osculum showed peak velocities at the center and diminishing velocities near the edges of the osculum. The degree of center-weighting was explained by the distribution of sponge biomass relative to the spongocoel. Volumetric pumping rates scaled isometrically with sponge size and averaged $0.06 \pm 0.04 \mathrm{l} \mathrm{s}^{-1} \mathrm{l}^{-1}$ sponge tissue, but were reduced for extremely large sponges. Pumping activity was relatively constant over short temporal scales, but varied over longer scales; however, variations in pumping rates, including periods of cessation, were asynchronous across the population and uncorrelated with changes in environmental conditions. We estimate that populations of $X$. muta in the Florida Keys and Bahamas process a volume of water equivalent to a layer 1.7 to $12.9 \mathrm{~m}$ thick each day and overturn the water column every 2.3 to $18.0 \mathrm{~d}$.
\end{abstract}

KEY WORDS: Volume flow $\cdot$ Porifera $\cdot$ Scaling · Water column turnover $\cdot$ Water velocity

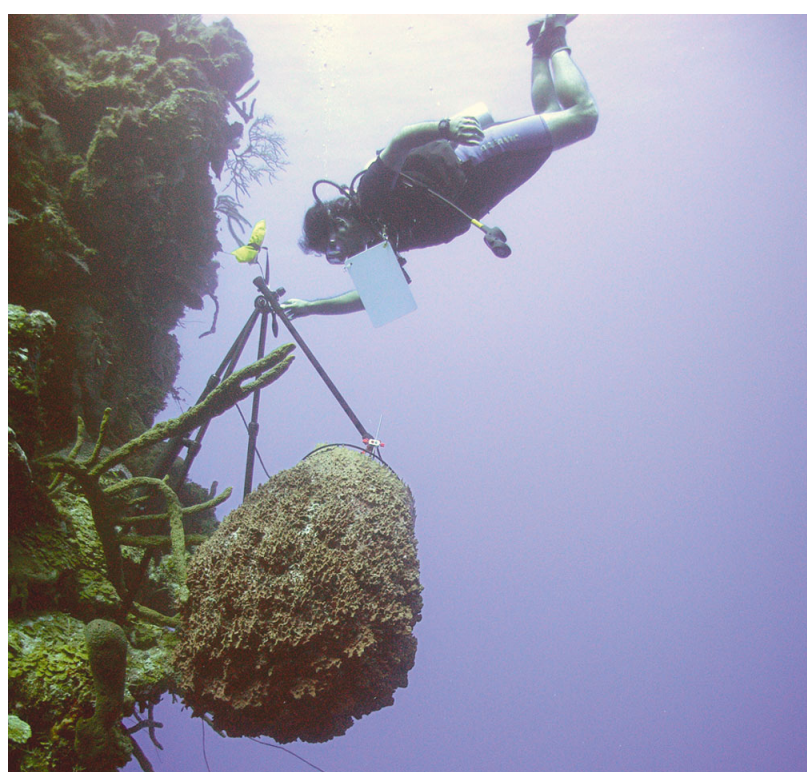

A diver positions an accoustic Doppler velocimeter over a Caribbean giant barrel sponge Xestospongia muta to measure the velocity of seawater pumped by the sponge.

Photo: Steven McMurray

\section{INTRODUCTION}

Benthic suspension feeders are important components of marine ecosystems (Gili \& Coma 1998). They efficiently process large volumes of water and thereby play important roles in benthic-pelagic coupling (Pile et al. 1997, Bak et al. 1998), organic matter cycling (Reiswig 1974, Yahel et al. 2003) and nutrient element cycling (Southwell et al. 2008, Fiore et al. 2013). By modifying the biotic and abiotic properties

() The authors 2014. Open Access under Creative Commons by Attribution Licence. Use, distribution and reproduction are unrestricted. Authors and original publication must be credited. 
of seawater, benthic suspension feeders mediate a number of direct and indirect ecological interactions. In shallow-water systems, and where they occur in dense assemblages, benthic suspension feeders may control phytoplankton biomass, thereby clarifying the water and increasing light availability to ecologically important benthic autotrophs (Cloern 1982, Officer et al. 1982). On coral reefs, benthic suspension feeders can deplete phytoplankton concentrations in overlying waters and represent an important pathway for the retention of allochthonous carbon and nutrients in coral reef ecosystems (Yahel et al. 1998, Monismith et al. 2010).

Sponges are benthic suspension feeders with a body plan that is specialized to actively pump large volumes of seawater (Larsen \& Riisgård 1994). Water enters the sponge through numerous incurrent pores, or ostia, which line the sponge surface, and then flows through a series of branching and successively narrowing incurrent canals to the water-pumping units, the choanocyte chambers. From here, water subsequently flows through a series of excurrent canals that merge and empty into the atrial cavity, the spongocoel, then to an excurrent osculum or oscula (Larsen \& Riisgård 1994). Volume flow through sponges has been estimated to range from 0.005 to $0.034 \mathrm{l} \mathrm{s}^{-1} \mathrm{l}^{-1}$ sponge tissue for Aplysina lacunosa to $0.578 \mathrm{l} \mathrm{s}^{-1} \mathrm{l}^{-1}$ sponge tissue for Callyspongia vaginalis (Weisz et al. 2008), and water column turnover estimates can range from $<1$ to $56 \mathrm{~d}$ for sponge assemblages at naturally occurring densities (Reiswig 1974, Pile et al. 1996, Savarese et al. 1997).

Pumping activity is required for sponges to feed and respire and is therefore strongly connected to sponge physiology and ecology. High excurrent seawater velocities that ensure the separation of incurrent and filtered seawater may be necessary for sponges to occupy low-flow habitats (Bidder 1923, Reiswig 1971, Riisgård et al. 1993). Sponges working at high internal pressures may be more susceptible to occlusion of the aquiferous system by sediment in low-energy habitats (Reiswig 1971). Pumping rates are also indicative of sponge life-history strategies and phenotype: sponge species with high microbial abundances (HMA) typically have a denser mesohyl, more complex aquiferous systems, lower densities of choanocyte chambers, possibly different feeding strategies, and lower pumping rates relative to low microbial abundance (LMA) species (Weisz et al. 2008).

The pumping activities of sponges also mediate numerous water column processes (Maldonado et al. 2012). For example, Baikalospongia bacillifera and $B$. intermedia from Lake Baikal, Russia, were found to remove $1870 \mathrm{mg} \mathrm{C} \mathrm{d} \mathrm{d}^{-1} \mathrm{~m}^{-2}$ of prokaryotic picoplankton, resulting in a picoplankton-depleted layer of water within $1 \mathrm{~m}$ of the benthos, but were a source of $750 \mathrm{mg} \mathrm{C} \mathrm{d}^{-1} \mathrm{~m}^{-2}$ of eukaryotic picoplankton (Pile et al. 1997). Sponges are also important in nitrogen cycling and release large amounts of dissolved inorganic nitrogen that may influence levels of primary production on coral reefs (Southwell et al. 2008, Fiore et al. 2013). Mass mortality of the Florida Bay sponge community resulted in an increase in the average water column turnover rate by as much as $12 \mathrm{~d}$ for some regions of the Bay and could account for the increased algal blooms reported there (Peterson et al. 2006). More recently, sponges have been described as essential to the cycling of carbon on coral reefs via the 'sponge loop', whereby sponges consume dissolved organic matter and make carbon available to other reef fauna in the form of detritus (de Goeij et al. 2013).

Sponges are found across a diversity of marine habitats, but are particularly dominant benthic suspension feeders on Caribbean coral reefs, where their biomass surpasses that of any other benthic group (Díaz \& Rützler 2001). Further, there is mounting evidence that sponges may be increasing in abundance on coral reefs (Colvard \& Edmunds 2011, Ruzicka et al. 2013). For example, populations of the giant barrel sponge Xestospongia muta in the Florida Keys increased by $46 \%$ between 2000 and 2006, and models indicate that populations will continue to increase (McMurray et al. 2010). Given forecasts of the negative effects of global warming and ocean acidification on reef-building corals, sponges may become increasingly more dominant on Caribbean coral reefs, and their roles in mediating water column processes may become even more substantial (González-Rivero et al. 2011, Bell et al. 2013).

To address needs for the implementation of ecosystem-based approaches to coral reef management (NOAA 2007), a greater understanding of the ecological processes mediated by sponges through their interactions with the water column is required. Detailed quantitative measurements of sponge pumping are necessary to scale material (e.g. carbon, nutrients) flux estimates from individuals to populations and to estimate the magnitude of spongemediated material fluxes. In this study, we investigated the pumping rates of the giant barrel sponge $X$. muta, a particularly dominant Caribbean coral reef sponge. $X$. muta is a large and long-lived species that can comprise up to $65 \%$ of the total sponge biomass on some reefs (McMurray et al. 2008, Southwell et al. 2008) and is the second most common sponge 
across the Caribbean on the basis of percentage cover (Loh \& Pawlik 2014). Our objectives were to determine how sponge size and morphology influence sponge pumping rates, and to determine how pumping may vary over time and with environmental changes. Results of this study are important in providing a foundation for subsequent quantitative work on the material fluxes mediated by sponges and will enable managers to better understand and predict the ecological consequences of those fluxes.

\section{MATERIALS AND METHODS}

\section{Study sites}

Pumping rates of Xestospongia muta were studied at sites in the Florida Keys (Conch Reef, $24^{\circ} 56.9^{\prime} \mathrm{N}$, $80^{\circ}$ 27.2' $\mathrm{W}$ and Pickles Reef, 24 $59.2^{\prime} \mathrm{N}, 80^{\circ} 24.6^{\prime} \mathrm{W}$ ) and the Bahamas (Great Stirrup Cay, 25 49.6' N, $77^{\circ}$ 53.9' W; Little San Salvador, $24^{\circ} 34.7^{\prime}$ N, $75^{\circ} 57.6^{\prime} \mathrm{W}$; Plana Cays, $22^{\circ} 36.4^{\prime} \mathrm{N}, 7^{\circ} 37.5^{\prime} \mathrm{W}$; San Salvador, $24^{\circ} 3.3^{\prime} \mathrm{N}, 74^{\circ} 32.5^{\prime} \mathrm{W}$; and Sweetings Cay, $26^{\circ} 34.1^{\prime} \mathrm{N}$, $\left.77^{\circ} 53.4^{\prime} \mathrm{W}\right)$. Water depths ranged from 15 to $30 \mathrm{~m}$. Aquarius Reef Base and the R/V 'Walton Smith', and the R/V 'Seward Johnson' were used as platforms for SCUBA diving at sites in the Florida Keys and Bahamas, respectively, over the course of 4 expeditions from 2007 to 2010. At each site, sponges representing a broad range of sizes (17.8 to $451649 \mathrm{~cm}^{3}$ ) were selected for study; however, only individuals with a single osculum and with no obvious signs of disease or tissue damage were included. Additionally, individuals fouled with algae or colonized by zoanthids were excluded, as epibionts have been shown to reduce sponge pumping rates (Lewis \& Finelli 2014). The proportion of sponges excluded from our study due to disease or fouling was $<2 \%$ at all sites; the proportions of multi-oscula sponges at our study sites ranged from $<1$ to $11 \%$. Before and during all pumping measurements, no physical contact was made with sponges.

\section{Distribution of velocities across the osculum}

In order to obtain precise estimates of sponge pumping rates, the mean excurrent velocity of flow from a sponge $\left(\bar{w}, \mathrm{~cm} \mathrm{~s}^{-1}\right)$ must be determined, which can be estimated from the distribution of velocities across the osculum plane. Profiles of excurrent velocities across the oscula of 10 sponges were measured using a Sontek Micro acoustic Doppler velocimeter

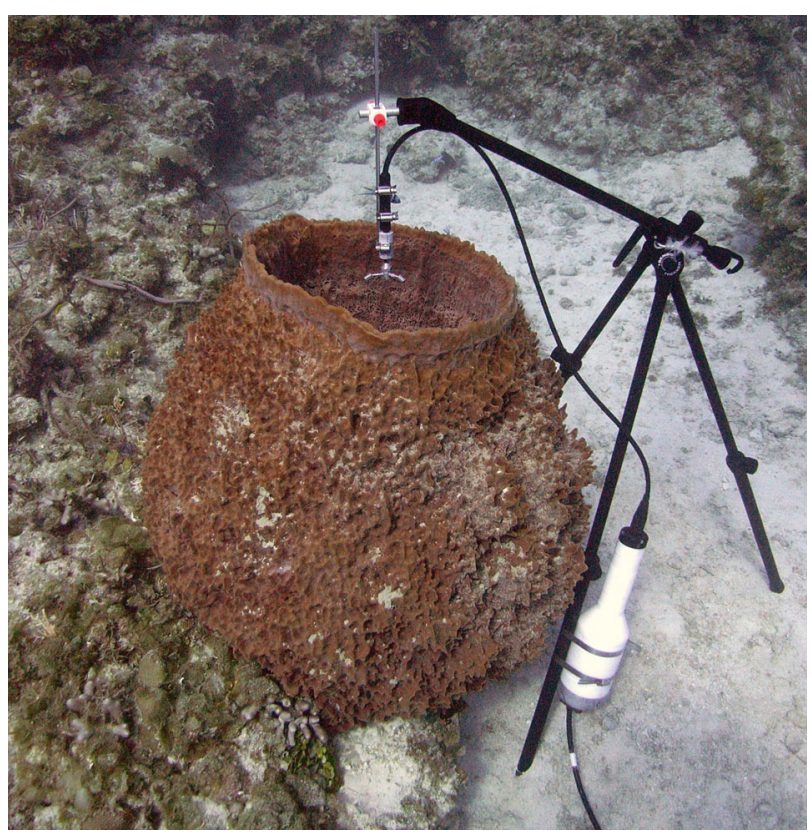

Fig. 1. The giant barrel sponge Xestospongia muta with an acoustic Doppler velocimeter (ADV) probe positioned over the sponge osculum to measure the velocity of excurrent seawater. Photograph: S. E. McMurray

(ADV) mounted on a tripod. The ADV probe was positioned vertically over each sponge (Fig. 1) so that the sample volume was located on the plane of the sponge osculum (Finelli et al. 1999a). For each sponge, excurrent velocity was measured at the osculum centerline ( $w_{\text {center }}$ ) and at points (4 to 11 , depending on the size of each sponge osculum) approximately every $3 \mathrm{~cm}$ across the osculum for $3 \mathrm{~min}$ at $5 \mathrm{~Hz}$. Following excurrent velocity measurements, sponge height, base circumference, osculum diameter, spongocoel depth and spongocoel base diameter were measured with a flexible plastic measuring tape and calipers. For size and morphology estimates, sponge and spongocoel volumes were approximated as a frustum of a cone, and areas of oscula and spongocoel bases were approximated as circles (McMurray et al. 2008).

Theory holds that 2 distinct velocity distributions, plug and parabolic, form the endpoints of a continuum exhibited as fluid flows through a pipe (Vogel 1994). For plug flow, velocities are equal across the osculum plane and $\bar{w}$ is equal to $w_{\text {center }}$. As fluid continues to flow in a rigid pipe, the effects of viscosity and friction ultimately produce flow for which the distribution of velocities is parabolic where $\bar{W}$ is equal to one-half of $w_{\text {center }}$ Notably, while water exiting the sponge osculum is not strictly analogous to flow through a rigid pipe, initial measurements suggested 
that the cross-osculum distributions of velocity were center-weighted such that $\bar{w}$ was a fraction of $w_{\text {center }}$. Therefore, profiles of excurrent velocities across the osculum were integrated gravimetrically to determine $\bar{w}$ by weighing velocity by the percent of the total osculum area between successive measurement points (Reiswig 1974). Because the morphology of the spongocoel has been shown to influence velocity profiles (Reiswig 1974), linear regression was used to determine the relationship between osculum diameter and the ratio of $\bar{w}$ to $w_{\text {center }}$ as well as the relationship between the ratio of osculum area $\left(A_{\text {osc }} \mathrm{cm}^{2}\right)$ to spongocoel base area $\left(A_{\mathrm{sb}}, \mathrm{cm}^{2}\right)$ and the ratio of $\bar{W}$ to $W_{\text {center }}$ For both regressions, variables were natural $\log$ transformed and ordinary least squares regression was used because a predictive relationship was sought (Warton et al. 2006).

\section{Scaling of pumping rates with sponge tissue volume}

The excurrent velocities and physical dimensions of a total of 235 sponges were measured to examine how pumping rates of $X$. muta scaled with sponge size. Excurrent seawater velocities were measured using either a Sontek MicroADV or Nortek ADV mounted on tripods with the ADV probe centered over the sponge and oriented such that $w_{\text {center }}$ was measured. Excurrent velocities of each sponge were measured over a 2 to $3 \mathrm{~min}$ sampling period at 4 or $5 \mathrm{~Hz}$. Following velocity measurements, the dimensions of each sponge were measured as described above.

In addition to examining how excurrent velocity was distributed across the osculum, we explored how excurrent velocity and volumetric pumping scaled with sponge morphology. For example, if the number of choanocyte chambers increases proportionally with sponge volume $\left(V_{\text {sponge, }} \mathrm{cm}^{3}\right)$ and all are active at the same time under the same pressures, $\bar{w}$ is expected to scale linearly with sponge size. Similarly, for a given excurrent volume flow, $\bar{W}$ should increase as $A_{\text {osc }}$ decreases. Additionally, results from velocity profiles indicated that $\bar{W}$ is affected by spongocoel morphology such that, for a given sponge size, $\bar{W}$ increases as the ratio of $A_{\mathrm{sb}}$ to $A_{\mathrm{osc}}$ increases (i.e. the spongocoel becomes more cylindrical rather than conical). To test these hypotheses, $\bar{W}$ was first plotted against the ratio of $V_{\text {sponge }}$ to $A_{\text {osc }}$ and reduced-major-axis (RMA) regression was used to describe the relationship. The fit of this regression was then compared with the RMA regression of $\bar{W}$ versus the ratio of $\left(V_{\text {sponge }} / A_{\mathrm{osc}}\right) /\left(A_{\mathrm{osc}} / A_{\mathrm{sb}}\right)$ to examine the change in the variation of $\bar{W}$ explained by considering sponge morphology.
Unlike some sponge species that may contract (Reiswig 1971), the osculum of $X$. muta is rigid and invariant; therefore, volume flow (i.e. pumping rate) through each sponge was calculated as:

$$
Q=\bar{W} \times A_{\mathrm{osc}}
$$

where $Q$ is volume flow $\left(\mathrm{ml} \mathrm{s}^{-1}\right)$. The relationship between $Q$ and $V_{\text {sponge }}$ was described by the allometric equation:

$$
Q=\alpha V_{\text {sponge }}^{\beta}
$$

Data were $\log _{10}$ transformed and RMA regression was performed to determine the scaling coefficient, $\alpha$, and the scaling exponent, $\beta$ of Eq. (2) (Warton et al. 2006). The $T$ statistic was used to test the actual slope against an isometric slope of $\beta=1$ (McArdle 1988). ANCOVA was used to test for differences in $Q$ between sites with $V_{\text {sponge }}$ as the covariate and site as a fixed factor.

The cycle time (sensu Reiswig 1974), or time required for a sponge to pump a volume of water equivalent to its volume, for each sponge was calculated by dividing $V_{\text {sponge }}$ by $Q$. Water-column transport rates for populations of $X$. muta were calculated as the product of the mean biomass of $X$. muta per unit area and the mean rate of volume flow found here $\left(0.06 \mathrm{l} \mathrm{s}^{-1} \mathrm{l}^{-1}\right)$. The biomass of $X$. muta at Sweetings Cay $(n=5)$ and San Salvador $(n=4)$, Bahamas, was estimated by measuring the size of all singleosculum individuals within haphazardly placed replicate $10 \mathrm{~m}$ diameter circular transects. For sites in the Florida Keys, biomass estimates were obtained from the literature: $1488 \mathrm{~cm}^{3} \mathrm{~m}^{-2}$ for the population on Conch Reef in 2006 over 15, 20, and $30 \mathrm{~m}$ depths (McMurray et al. 2010), and 1609, 2100, and $960 \mathrm{~cm}^{3}$ $\mathrm{m}^{-2}$ for populations on offshore reefs in the Upper, Middle, and Lower Florida Keys, respectively, in 2007 (Bertin \& Callahan 2008). The estimated time for these populations to overturn a water column $30 \mathrm{~m}$ deep was calculated as the ratio of the water column depth (i.e. $30 \mathrm{~m}$ ) and the estimated water column transport rates. We note that the biomass estimates reported here for sites in the Bahamas and those reported for Conch Reef, Florida (McMurray et al. 2010) do not include the biomass of multi-oscula individuals $(<11 \%$ of the population); thus, water column transport and turnover rates for these sites are conservative estimates.

$X$. muta harbors cyanobacterial symbionts in peripheral tissues that impart a reddish-brown coloration to individuals; however, individuals may lose symbionts and appear bleached (McMurray et al. 2011). Although available evidence suggests that this type 
of bleaching is not a stressful condition, the pigmentation of a subset of sponges studied was scored as either normal or bleached to investigate the relationship between pumping rates and sponge bleaching (McMurray et al. 2011). A 1-way ANCOVA with $V_{\text {sponge }}$ as the covariate and bleaching as a fixed factor was conducted to test for differences in $Q$ between bleached and unbleached sponges.

\section{Temporal variation in pumping and environmental variables}

Long-term measurements of sponge pumping were conducted to examine temporal variation in pumping rates and the sensitivity of pumping to environmental changes. ADVs were positioned over sponges as described above to measure $w_{\text {center }}$ for 2 to 4 min intervals every 3 to $10 \mathrm{~min}$ at 4 to $5 \mathrm{~Hz}$. Measurement periods ranged from 15 to $60 \mathrm{~h}_{\text {; }}$ of the 29 sponges measured, 26 were measured for $>22 \mathrm{~h}$, 11 were measured for $>30 \mathrm{~h}$, and 4 sponges were measured for $>46 \mathrm{~h}$. During each deployment, excurrent velocities of 2 to 4 sponges were measured simultaneously with multiple ADVs. Following excurrent velocity measurements, the physical dimensions of each sponge were measured as described above.

Seawater temperature was measured by each ADV within $1 \mathrm{~m}$ of each observed sponge. Additional concurrent measurements of turbidity, dissolved oxygen, conductivity, $\mathrm{pH}$, and pressure were made using a Eureka Environmental Engineering Manta Multiprobe mounted on a tripod and placed within $10 \mathrm{~m}$ of measured sponges. Measurements of ambient currents were made using a Nortek Aquadopp acoustic Doppler profiler deployed on the seafloor adjacent to the area where sponge pumping was measured. Times of sunrise and moonrise, as well as sunset and moonset during measurement intervals for each site were obtained from the Astronomical Applications Department of the United States Naval Observatory. Time series analysis was applied to pumping and environmental data to determine any periodicities over time (Box et al. 1994). Analysis of the crossspectral densities was used to investigate the relationship between pumping and environmental variables (Finelli et al. 1999b). Differences in the standard deviation of excurrent velocity at night versus day were tested with a 2-way mixed model ANOVA with sponge as a random factor and daylight as a fixed factor. Analyses were conducted with SAS (version 9.1.3 for Windows; SAS Institute) and SPSS (version 14.0.0 for Windows; SPSS) statistical software.

\section{RESULTS}

Profiles of excurrent seawater velocities across the osculum plane of Xestospongia muta were nonuniform, with ratios of $\bar{w}$ to $W_{\text {center }}$ ranging from 0.16 to 0.92 (mean $\pm \mathrm{SD}=0.46 \pm 0.29, \mathrm{n}=10$ ). Those profiles with $\bar{W}$ to $W_{\text {center }}$ ratios $\sim 1$ were plug-like, those with ratios $\sim 0.5$ were parabolic, and those with ratios $<0.5$ were strongly center-weighted with diminished flows near the osculum edges. There was no relationship between profile velocity distributions and sponge osculum diameter $(\mathrm{p}=0.49)$; however, the ratio of $\bar{w}$ to $W_{\text {center }}$ was found to allometrically decrease as $A_{\text {osc }}$ increased relative to $A_{\mathrm{sb}}\left(\mathrm{r}^{2}=0.60, \mathrm{p}=0.008, \mathrm{n}=10\right)$ (Fig. 2). The allometric equation relating the ratio of $\bar{W}$ to $W_{\text {center }}$ to the ratio of $A_{\mathrm{osc}}$ to $A_{\mathrm{sb}}$ was determined to be:

$$
\frac{\bar{W}}{W_{\text {center }}}=1.73\left(\frac{A_{\text {osc }}}{A_{\mathrm{sb}}}\right)^{-0.52}
$$

and this relationship was subsequently used to correct all excurrent velocities for the non-uniform distribution across the osculum of each sponge. Eq. (3) indicates that the distribution of velocities across the osculum become more uniform as the spongocoel becomes more cylindrical, rather than conical. Plug flow (i.e. $\bar{W}=w_{\text {center }}$ ) results when $A_{\text {osc }}$ is approximately 2.87 times $A_{\mathrm{sb}}$, near-parabolic (i.e. $\bar{W}=0.5 \times$ $W_{\text {center }}$ ) flow occurs at $A_{\text {osc }}$ to $A_{\mathrm{sb}}$ ratios $\sim 10$, and strongly center-weighted flow (i.e. $\bar{W}<0.5 \times w_{\text {center }}$ ) occurs at $A_{\mathrm{osc}}$ to $A_{\mathrm{sb}}$ ratios $>10$. The relationship between spongocoel morphology and excurrent flow (Eq. 3) was found to be explained by the partitioning

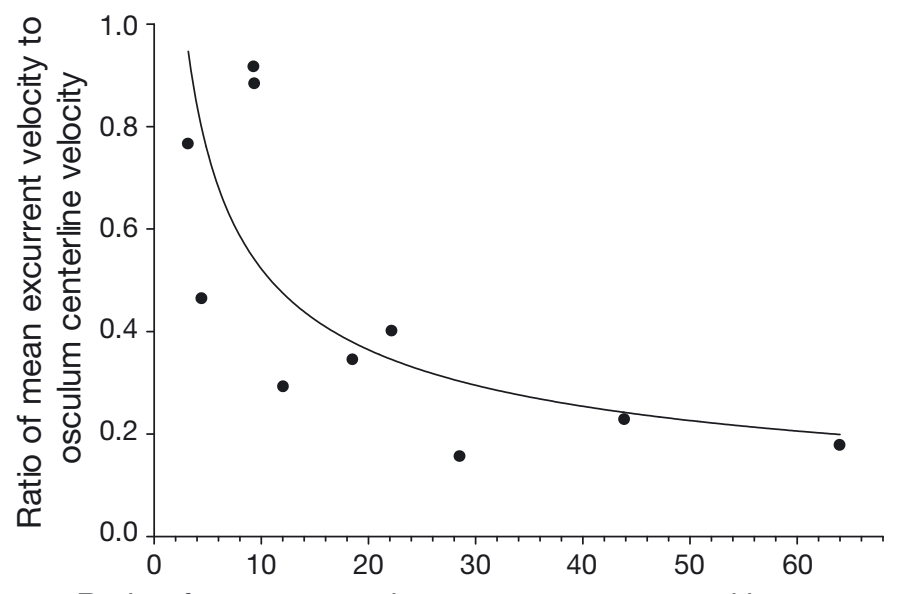

Ratio of sponge osculum area to spongocoel base area

Fig. 2. Relationship between excurrent velocity distributions and spongocoel morphology, showing the ratio of mean excurrent velocity $(\bar{w})$ to velocity at the osculum centerline $\left(w_{\text {center }}\right)$ vs. the ratio of sponge osculum area $\left(A_{\text {osc }}\right)$ to spongocoel base area $\left(A_{\mathrm{sb}}\right)$. Fitted line is Eq. (3) 
of sponge biomass relative to the spongocoel (see the Supplement at www.int-res.com/articles/suppl/b023 p001_supp.pdf).

Mean excurrent velocities ranged from 0.03 to $13.66 \mathrm{~cm} \mathrm{~s}^{-1}$ and increased linearly as a function of the ratio of $V_{\text {sponge }}$ to $A_{\text {osc }}\left(\mathrm{r}^{2}=0.27, \mathrm{p}<0.001, \mathrm{n}=235\right)$. Much more of the variation in $\bar{W}$ was explained when spongocoel morphology was additionally considered by standardizing the ratio of $V_{\text {sponge }}$ to $A_{\text {osc }}$ by the ratio of $A_{\text {osc }}$ to $A_{\mathrm{sb}}\left(\bar{W}=0.22\left[V_{\text {sponge }} / A_{\text {osc }}\right] /\left[A_{\text {osc }} / A_{\text {sb }}\right]+1.46\right)$ $\left(\mathrm{r}^{2}=0.5, \mathrm{p}<0.001, \mathrm{n}=235\right)$ (Fig. 3). While pumping activity was relatively constant during the 3 min intervals over which measurements were made, excurrent velocities were found to vary over longer temporal scales (see below). To examine how this variation affected estimates of $\bar{W}$, we regressed $\bar{W}$ computed for all long-term ADV deployments (15 to $60 \mathrm{~h}$ ) against the ratio of $\left(V_{\text {sponge }} / A_{\text {osc }}\right) /\left(A_{\text {osc }} / A_{\mathrm{sb}}\right)$. Consideration of the long-term temporal variation of pumping activity by sponges further increased the amount of variation in $\bar{w}$ explained by sponge and spongocoel morphology $\left(\mathrm{r}^{2}=0.65, \mathrm{p}<0.001, \mathrm{n}=29\right)$.

Tissue volumes of measured sponges ranged from 17.8 to $451649 \mathrm{~cm}^{3}$. Volume flow increased isometrically with increasing sponge volume and is reliably predicted from sponge volume $(T=1.33, \mathrm{df}=170$, $\mathrm{r}^{2}=0.78, \mathrm{p}<0.001$ ) (Fig. 4). The equation relating $Q$ to $V_{\text {sponge }}$ was determined to be:

$$
Q=0.02 V_{\text {sponge }}^{1.1}
$$

The mean $( \pm \mathrm{SD})$ volume flow, standardized to sponge tissue volume, was $0.06 \pm 0.04 \mathrm{l} \mathrm{s}^{-1} \mathrm{l}^{-1}$. RMA regression of $Q$ computed for all long-term pumping measurements against $V_{\text {sponge }}$ was found to increase the amount of variation in $Q$ explained by $V_{\text {sponge }}\left(\mathrm{r}^{2}=\right.$ $0.82, \mathrm{p}<0.001, \mathrm{n}=29$ ). There was no significant difference in volume flow between sites $\left(F_{6,227}=1.36\right.$, $\mathrm{p}=0.23$ ) or between bleached and unbleached sponges $\left(F_{1,163}=0.07, \mathrm{p}=0.80\right)$.

While an isometric relationship was found between $Q$ and $V_{\text {sponge, }}$ further inspection of the data revealed that $Q$ was reduced for 3 to 5 of the largest individuals measured (Fig. 4). The removal of the 3 largest individuals from the dataset did not significantly change the results of the regression of $Q$ versus $V_{\text {sponge }}\left(T=1.47, \mathrm{df}=168, \mathrm{r}^{2}=0.77, \mathrm{p}<0.001\right)$. Additionally, 4-parameter log-normal and Weibull curves were fit to the data using non-linear regression. Only the fit of the Weibull curve $\left(\mathrm{r}^{2}=0.78, \mathrm{p}<0.001\right)$ was comparable to that found for Eq. (4) (Fig. 4); however, given the complexity of the Weibull function, Eq. (4) was chosen as the most parsimonious model to describe sponge pumping.

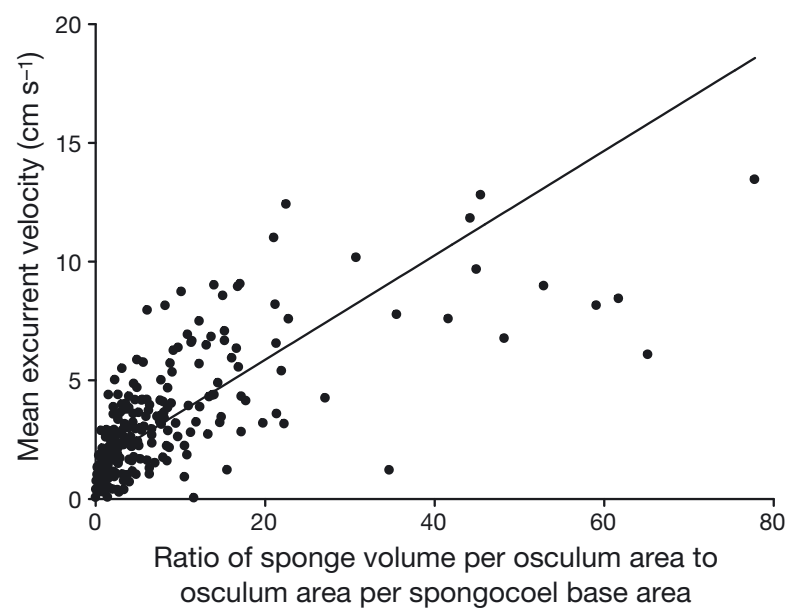

Fig. 3. Scaling relationship between excurrent velocity and sponge size and morphology: mean excurrent velocity $(\bar{W})$ vs. the ratio of sponge volume ( $\left.V_{\text {sponge }}\right)$ to osculum area $\left(A_{\text {osc }}\right)$ standardized to the ratio of $A_{\mathrm{osc}}$ to spongocoel base area $\left(A_{\mathrm{sb}}\right)$

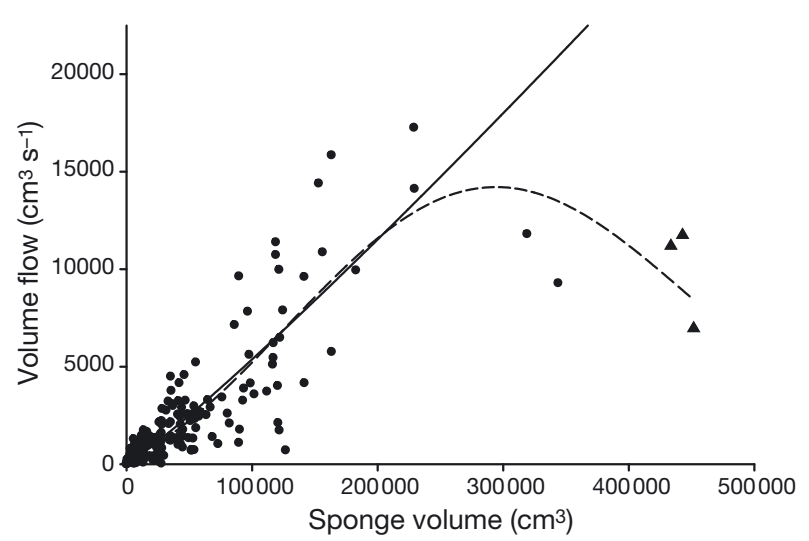

Fig. 4. Volume flow $(Q)$ vs. sponge volume ( $\left.V_{\text {sponge }}\right)$; solid fitted line is the allometric equation (Eq. 4), dashed fitted line is a 4-parameter Weibull curve. Triangles indicate the 3 largest individuals that had reduced pumping rates relative to all other individuals

The mean $( \pm \mathrm{SD})$ cycle time for $X$. muta was determined to be $30 \pm 33 \mathrm{~s}$. The biomass of $X$. muta was determined to be $321 \pm 293 \mathrm{~cm}^{3} \mathrm{~m}^{-2}$ off Sweetings Cay and $2480 \pm 1612 \mathrm{~cm}^{3} \mathrm{~m}^{-2}$ off San Salvador; water transport rates at these sites were 1.7 and $12.9 \mathrm{~m} \mathrm{~d}^{-1}$, respectively. Populations of $X$. muta on Conch Reef and on reefs in the Upper, Middle, and Lower Florida Keys were found to transport water at rates of 7.7, 8.3, 10.9, and $5.0 \mathrm{~m} \mathrm{~d}^{-1}$, respectively. Given these rates, populations of $X$. muta were estimated to overturn a water column 30 m deep every 3.9, 3.6, 2.8, and $6.0 \mathrm{~d}$ on Conch Reef and the Upper, Middle, and Lower Florida Keys, respectively. Water column turnover estimates were $18.0 \mathrm{~d}$ for $X$. muta off Sweetings Cay and $2.3 \mathrm{~d}$ for $X$. muta off San Salvador. 
Spectral analysis of long-term excurrent velocity measurements indicated pumping was relatively constant over time for the majority of sponges measured (Fig. 5), but there were exceptions to this generality. The largest variation in pumping occurred for 3 sponges that demonstrated a nearly simultaneous decrease in $W_{\text {center }}$ by 12 to $16 \mathrm{~cm} \mathrm{~s}^{-1}$ over a $32 \mathrm{~h}$ measurement interval (Figs. $5 \& 6 \mathrm{~A}$ ). The decrease in pumping activity started at approximately sunset, continued through sunrise, and corresponded with a decrease in dissolved oxygen and $\mathrm{pH}$ (Fig. 6). Near the end of this interval, complete cessation of pumping occurred for 1 sponge (sponge ID 2) for $10 \mathrm{~min}$ and another sponge (sponge ID 1) had significantly reduced or no pumping for nearly $3 \mathrm{~h}$ before pumping resumed (Fig. 6A). Pumping cessation for sponge ID 1 was associated with an increase in temperature, dissolved oxygen, and pH (Fig. 6).

Rapid decreases in pumping and near or total cessation of activity was observed for 6 sponges. Pumping cessation typically occurred at night, with pumping activity resuming just before sunrise (e.g. sponge ID 5, Fig. 7). For 3 of these sponges, decreases were brief, lasting approximately $10 \mathrm{~min}$, and pumping was observed to recover to prior levels thereafter. For the remaining 3 sponges, pumping cessation lasted between 100 and 230 min before recovery. With the exception of the sponges measured in Fig. 6A, pumping cessation was not synchronous between neighboring sponges (Fig. 7).

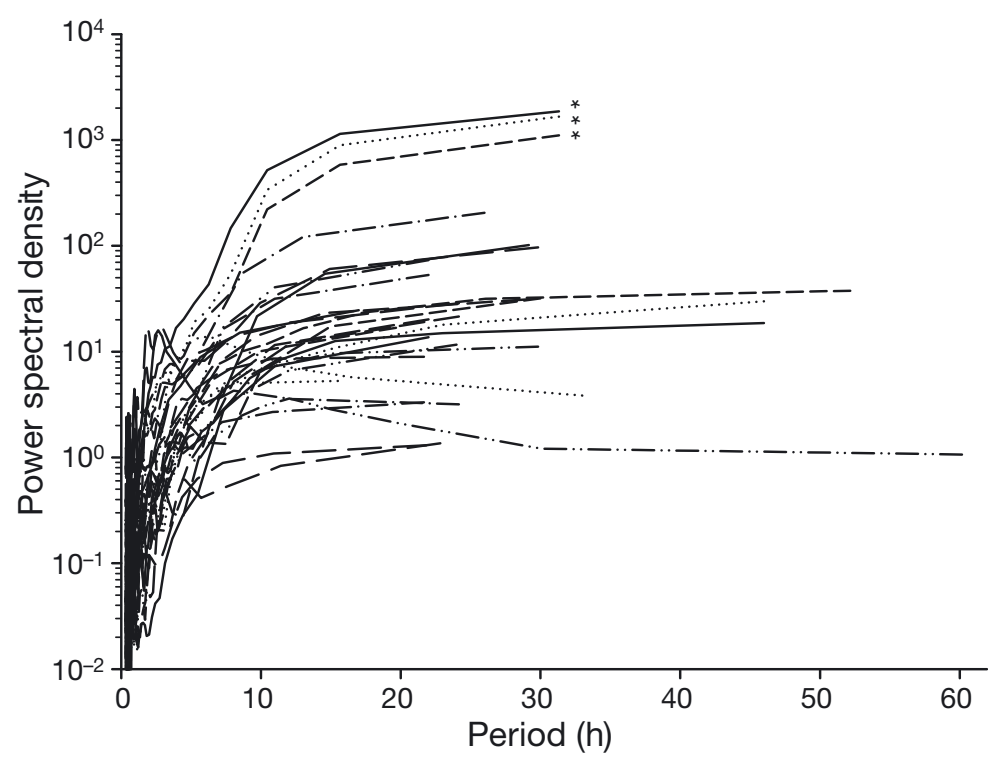

Fig. 5. Power spectral density (log-scale) vs. period for all long-term mean excurrent velocity measurements $(n=29)$. Asterisks denote the 3 sponges with the greatest variation in pumping; excurrent velocities of these sponges are plotted over time in Fig. 6A
The ranges of environmental variables measured over long-term sponge pumping measurements were temperature $\left(24.8\right.$ to $\left.29.7^{\circ} \mathrm{C}\right), \mathrm{pH}(8.0$ to 8.9$)$, conductivity ( 54.7 to $55.6 \mathrm{mS} \mathrm{cm}^{-1}$ ), turbidity ( -0.9 to $5 \mathrm{NTU}$ ), and dissolved oxygen (4.7 to $7.7 \mathrm{ppm}$ ). Excurrent velocities and environmental variables were found to vary over periods corresponding to the tides (Fig. 8); however, cross-spectral analysis of long-term excurrent velocity and environmental data indicated that no one parameter could explain pumping variation by sponges. Both positive and negative correlations were found between excurrent velocities and environmental variables, but these correlations were not consistent between sponges or over similar ranges of environmental variables. In addition, simultaneous measurements on multiple sponges, within close proximity to each other and under similar environmental conditions, often revealed asynchronous temporal pumping patterns between adjacent sponges (Fig. 7). There was no relationship between excurrent velocities and ambient currents, lunar cycles, or daylight.

\section{DISCUSSION}

\section{Pumping rates and sponge size}

The active pumping of water is central to sponge biology and has important implications on all levels of ecological organization ranging from that of the individual (e.g. physiology) to entire ecosystems (e.g. carbon cycling). Moreover, given current and projected future states of coral reef ecosystems (Hoegh-Guldberg et al. 2007), there is a particular need to understand the magnitude of interactions mediated by sponges through the water column. Despite this and the development of advanced instrumentation to measure water velocity (e.g. ADVs), there have been surprisingly few comprehensive in situ studies of sponge pumping rates since the pioneering work of Reiswig (1971, 1974). Although, on an individual level, the excurrent velocities of Xestospongia muta were found to be influenced by sponge size and morphology, our measurements on 274 sponges at sites in the Florida Keys and Bahamas indicate that the volume of seawater (i.e. pumping rates) processed by sponges is largely explained and can be predicted from simple measurements of sponge size. The relationship between pumping rates and sponge size reported here can be applied 

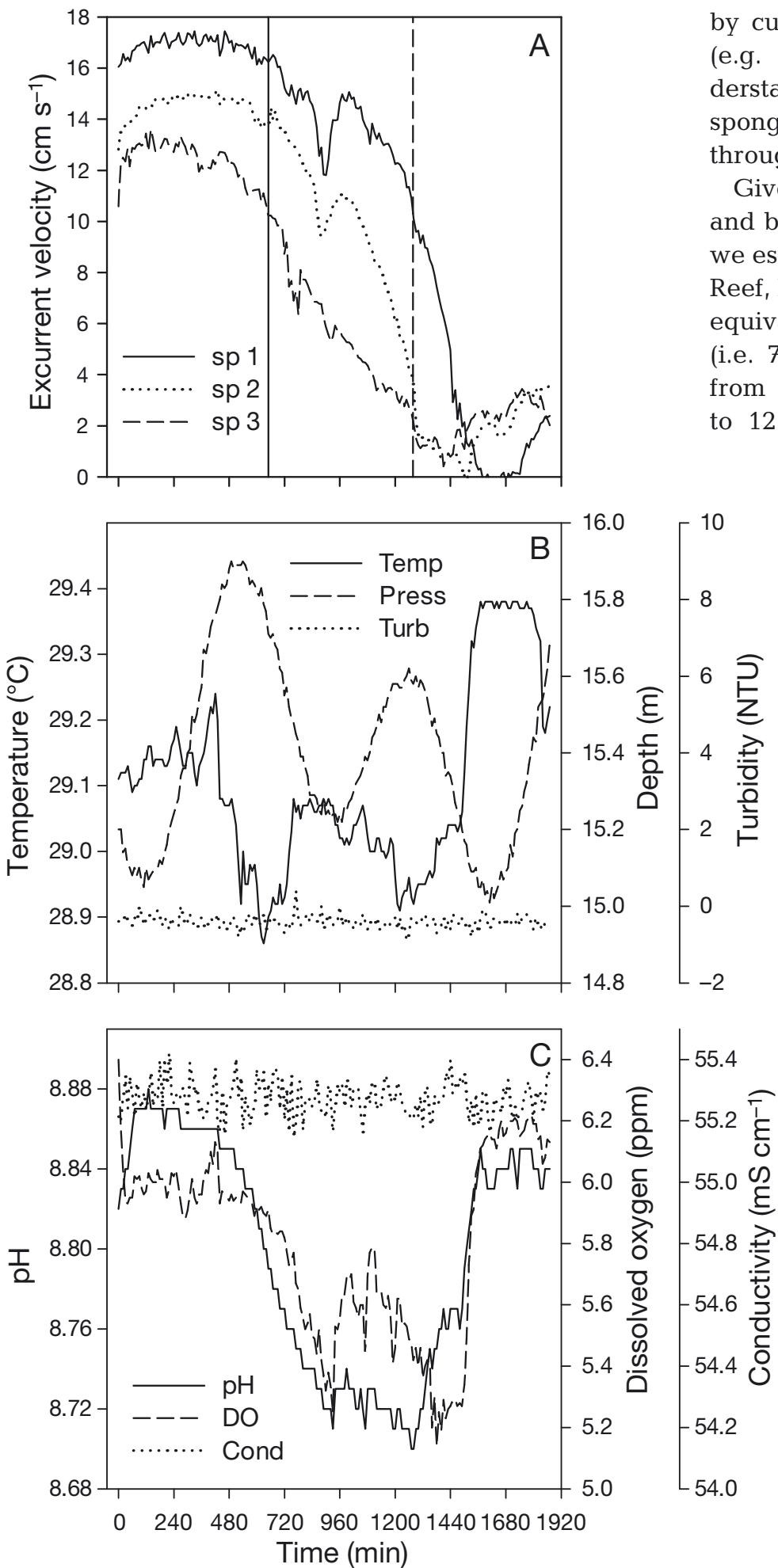

Fig. 6. Long-term 10 min means of (A) excurrent velocity at the osculum centerline $\left(w_{\text {center }}\right)$ for the 3 sponges $(\operatorname{sp~} 1,2$, and 3 ) with the greatest temporal variation in pumping, and simultaneous measurements of (B) temperature (Temp), pressure (Press), and turbidity (Turb), and (C) $\mathrm{pH}$, dissolved oxygen (DO), and conductivity (Cond) plotted over time. Solid vertical line indicates time of sunset; dashed vertical line indicates time of sunrise by current and future coral reef monitoring efforts (e.g. Ruzicka et al. 2013) to obtain a better understanding of the magnitude of the influence of sponge populations on ecological processes mediated through the water column.

Given the mean rate of volume flow reported here and biomass estimates from McMurray et al. (2010), we estimate that the population of $X$. muta on Conch Reef, Key Largo, Florida processes a volume of water equivalent to a water layer $7.7 \mathrm{~m}$ thick every day (i.e. $7700 \mathrm{l} \mathrm{m}^{-2} \mathrm{~d}^{-1}$ ). Water transport rates ranged from $1700 \mathrm{l} \mathrm{m}^{-2} \mathrm{~d}^{-1}$ for $X$. muta off Sweetings Cay to $12900 \mathrm{l} \mathrm{m}^{-2} \mathrm{~d}^{-1}$ for $X$. muta off San Salvador, Bahamas. Using biomass estimates from a long-term coral reef monitoring program (Bertin \& Callahan 2008), populations in the Florida Keys are estimated to overturn a water column $30 \mathrm{~m}$ deep every 2.8 to $6.0 \mathrm{~d}$. Estimates of water column turnover for populations of $X$. muta in the Bahamas ranged from every 2.3 to $18 \mathrm{~d}$. We do note that, although sponge size is a significant predictor of pumping rates, these estimates do not account for temporal variations in pumping activity. Nonetheless, these rates for a single sponge species are significant when compared to estimates of water transport for the entire sponge community on the reefs of Discovery Bay, Jamaica, which range between 16.5 and $40 \mathrm{~m} \mathrm{~d}^{-1}$ (Reiswig 1974). If recent demographic trends of $X$. muta continue (McMurray et al. 2010), we predict that populations of $X$. muta will exert an even greater influence over water column processes on coral reefs of the future.

Volume flow was found to scale isometrically with sponge biomass, indicating that numbers of choanocyte chambers are proportional to tissue volume. This supports experimental work that demonstrated a correlation between pumping rates and choanocyte chamber density (Massaro et al. 2012) and is consistent with the view of sponges as functionally clonal organisms (Vermeij 1993). Interestingly, however, 3 to 5 extremely large individuals, uncommon on most coral reefs, had pumping rates that were proportionally less than smaller sponges. Sampling was limited by the availability of massive individuals, so the generality of this pattern is unclear. Nonetheless, the decrease in pumping observed for these individuals may reflect a physiological size limit (Reiswig 


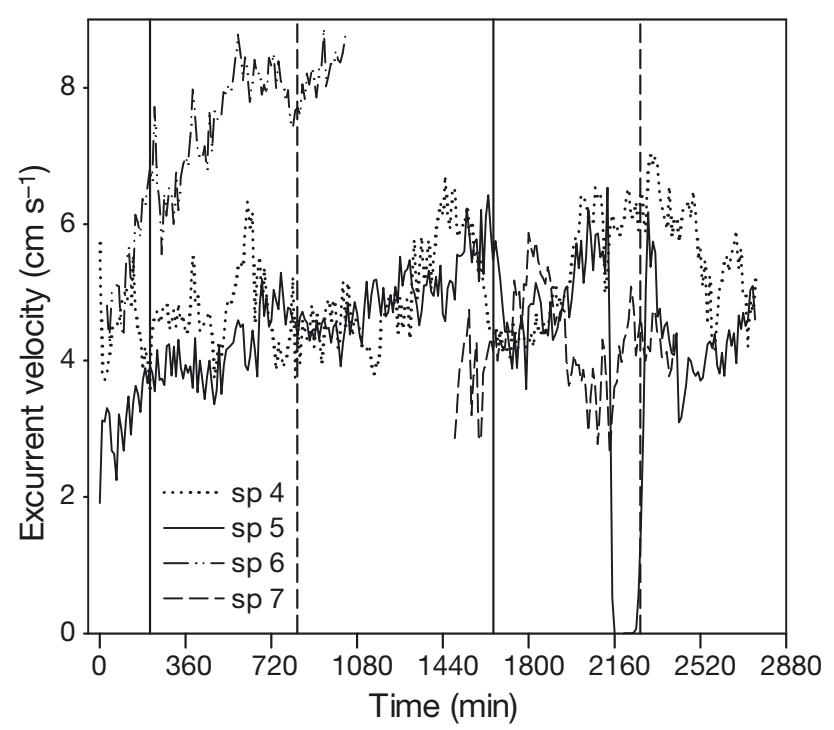

Fig. 7. Long-term 10 min means of excurrent velocity at the osculum centerline ( $\left.w_{\text {center }}\right)$ over time for 4 sponges $(\operatorname{sp} 4,5$, 6 , and 7). Velocity measurements for sponges 6 and 7 do not span the entire time interval. Solid vertical lines indicate time of sunset; dashed vertical lines indicate time of sunrise

1974, Riisgård et al. 1993) or other factors associated with the greater age of these individuals (McMurray et al. 2008). Additionally, sponge volume estimates derived here for the largest individuals may overestimate the volume of live tissue if the biomass of these individuals is disproportionally occupied by sand, symbionts (e.g. polychaetes), or other non-living components. Within 4 species investigated by Reiswig (1974, 1981), pumping rates were nearly constant across a range of body sizes for 3 species, although the largest specimens of Verongia reiswigi (V. gigantea in Reiswig 1974) had lower tissue-specific pumping rates, while pumping rates generally decreased with sponge size for Aplysina fistularis ( $V$. fistularis in Reiswig 1981).

The mean specific volume flow of $0.06 \pm 0.04 \mathrm{l} \mathrm{s}^{-1}$ $\mathrm{l}^{-1}$ reported in this study is similar to the mean of $0.078 \mathrm{l} \mathrm{s}^{-1} \mathrm{l}^{-1}$ found for 5 individuals of $X$. muta in the Florida Keys (Weisz et al. 2008) and $0.044 \pm 0.007 \mathrm{l} \mathrm{s}^{-1}$ $\mathrm{l}^{-1}$ found for 22 individuals at sites in the Florida Keys and Bahamas (Lewis \& Finelli 2014). Pumping rates for $X$. muta are generally similar to those reported for other HMA sponges, which are consistently lower than those for LMA sponges (Weisz et al. 2008). The mean $( \pm \mathrm{SD})$ cycle time, or time required for a sponge to pump a volume of water equivalent to its volume, was determined to be $30 \pm 33$ s for $X$. muta. The cycle times for the HMA species $V$. reiswigi and Tectitethya crypta (Tethya crypta in Reiswig 1974) were
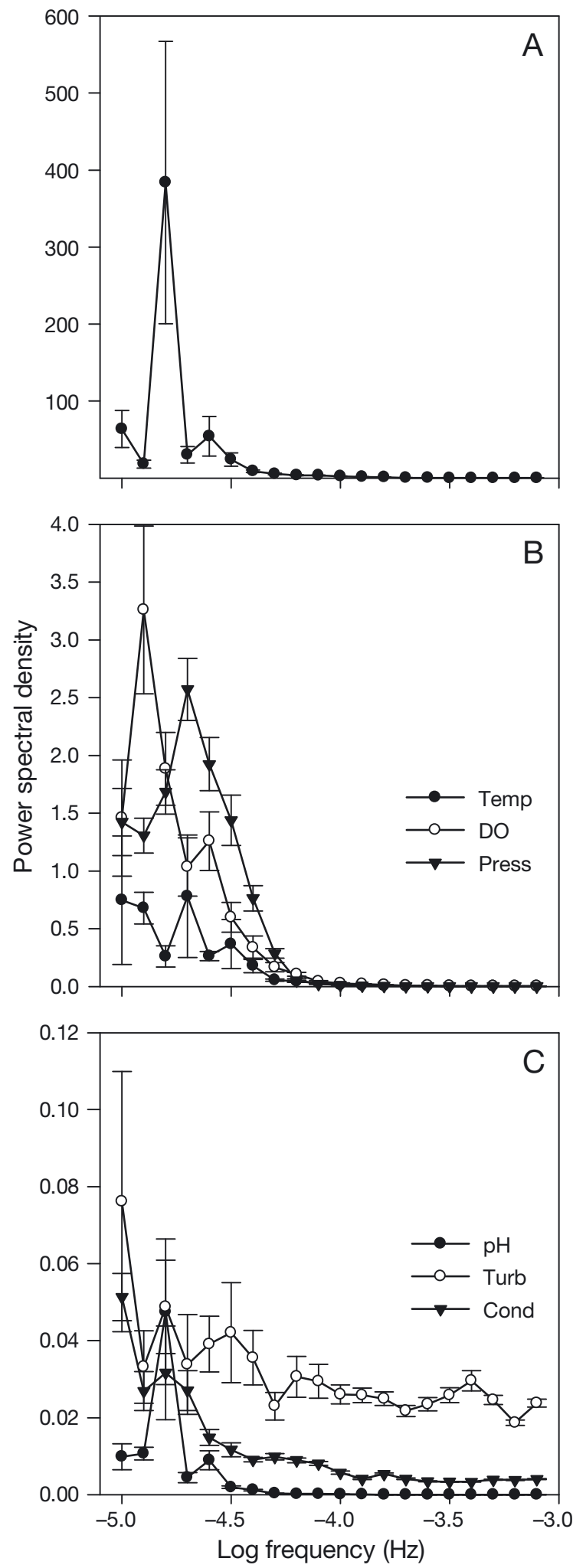

Fig. 8. Mean $( \pm \mathrm{SD})$ power spectral density estimates vs. log frequency for long-term records of (A) excurrent velocities at the osculum centerline ( $\left.w_{\text {center }}\right)$, $(\mathrm{B})$ temperature (Temp), dissolved oxygen (DO), and pressure (Press), and (C) $\mathrm{pH}$, turbidity (Turb), and conductivity (Cond) 
approximately 19 and $22 \mathrm{~s}$, respectively (Reiswig 1974). Despite having relatively lower pumping rates per unit tissue volume than many LMA species, the biomass of $X$. muta exceeds that of all other species (Southwell et al. 2008); thus, this one dominant species may have a disproportionate effect on water column processing.

\section{Excurrent seawater velocities and sponge morphology}

Our measurements of pumping by $X$. muta revealed a close association between sponge form (i.e. size and morphology) and function. Results indicate that distributions of velocities across the sponge osculum are more typically non-uniform (nearparabolic) but velocity profiles spanned the spectrum from near-plug flow to strongly center-weighted. Velocity profiles were not correlated with the diameter of the osculum, suggesting that the effects of viscosity and wall friction are negligible. Rather, the morphology of the spongocoel, specifically the ratio of the areas of the osculum and spongocoel base (i.e. the degree to which the spongocoel was cylindrical rather than conical), largely determines velocity distributions. The large range of excurrent profiles reported here emphasizes the need for such measurements to accurately estimate sponge pumping rates. For example, the mean pumping rate for 12 specimens of $X$. muta on Conch Reef, Florida, and Lee Stocking Island, Bahamas, estimated by Fiore et al. (2013) by measuring the speed of dye fronts at the osculum centerline and assuming plug flow $(0.12 \pm$ $0.13 \mathrm{l} \mathrm{s}^{-1} \mathrm{l}^{-1}$; calculated from data in Fiore et al. 2013, their Table 1) is double the mean pumping rate found in the present study.

This is the first study since the work of Reiswig (1974) to directly investigate the relationship between spongocoel morphology and excurrent flow. Profile correction factors for Mycale laxissima (Mycale sp. in Reiswig 1974) ranged between 0.88 and 0.98 and were found to become more parabolic as the ratio of osculum diameter to spongocoel diameter increased and approached 1 (Reiswig 1974). Profiles of $V$. reiswigi and Haliclona permollis were also center-weighted, with correction factors of 0.86 and 0.58 , respectively, but a relation with spongocoel morphology was not reported (Reiswig 1974, 1975). There is a paucity of available comparative data, however, the range of velocity distributions for $X$. muta $\bar{W}=0.16$ to 0.92 times $\left.W_{\text {center }}\right)$ is large relative to those for other sponges. This is likely the result of the much larger ranges of sizes and morphologies of $X$. muta compared to other species considered.

Despite early recognition that excurrent velocity distributions are affected by the morphology of the spongocoel (Reiswig 1974), an explanation of this relationship has been lacking. Our model of sponge morphology and flow (see the Supplement at www.int-res.com/articles/suppl/b023p001_supp.pdf) closely approximated the relationship observed between spongocoel morphology and velocity distributions, and suggests that the partitioning of sponge biomass relative to the spongocoel influences excurrent water flow. According to the model of sponge morphology and flow, changes in the morphology of the spongocoel are concomitant with changes in the distribution of sponge biomass between wall and base regions of the sponge that drain excurrent flow through the peripheral and central regions of the osculum, respectively. Sponges with larger osculum area to spongocoel base area ratios (i.e. v-shaped spongocoels) tend to have more biomass partitioned in walls relative to the base region. However, because the osculum is much wider for v-shaped spongocoels relative to cylindrical spongocoels, excurrent seawater from sponge walls exits a much larger area of the osculum and velocity is reduced relative to that at the centerline, resulting in parabolic-like flow. The implication of this relationship is that sponges with v-shaped spongocoels have reduced $\bar{w}$ relative to sponges of similar biomass with cylindrical spongocoels.

It is unclear why such large variation in spongocoel morphologies occurs, independent of sponge size, given the effects of morphology on excurrent seawater velocities. The speed at which water is ejected from the osculum has been hypothesized to be important in the separation of incurrent and filtered water (Bidder 1923, Riisgård et al. 1993). It is likely that ambient currents of habitats where $X$. muta typically occur are of sufficient strength to provide individuals a continuous supply of unfiltered seawater (e.g. Monismith et al. 2010). However, it remains to be seen if morphological differences reflect spatial variability of the flow regime across coral reefs. Morphological variation in $X$. muta may also indicate adaptation to a number of other environmental factors (Meroz-Fine et al. 2005). Individuals of $X$. muta with divergent external morphologies have been shown to have different haplotypes; therefore, it may be that morphology is largely genetically determined (LópezLegentil \& Pawlik 2009). Similarly, differences in morphology and pumping may be a function of gender differences within the population (Reiswig 1974). 
$X$. muta is dioecious and reproduces sexually during mass spawning events (Ritson-Williams et al. 2005). While the relationship between morphology and gender of $X$. muta remains to be investigated, anecdotal observations during spawning events suggest that males may have more cylindrical chimney-like morphologies, while females may have more bowl-like morphologies with v-shaped oscula (S. E. McMurray pers. obs.).

Mean excurrent velocities scaled linearly with the ratio of $V_{\text {sponge }}$ to $A_{\text {osc }}$ suggesting that volume flow is isometric with sponge size; however, there was large variation in $\bar{w}$. Some of this variation was explained by considering spongocoel morphology. Calculation of $\bar{W}$ over longer temporal scales further increased the variation explained by sponge size and spongocoel morphology, suggesting that variation in $\bar{w}$ is partly due to temporal changes in pumping activity by sponges. Variation in $\bar{w}$ may also be due to differences in the proportion of choanocyte chambers between sponges, as was found between male and females for the sponge V. reiswigi (Reiswig 1974). The diameter of internal aquiferous canals of the intertidal sponge Halichondria panacea was found to decrease in response to high wave force (Palumbi 1986). Changes in $\bar{w}$ would be expected to be concomitant with such changes, but it is unknown whether the aquiferous system architecture of $X$. muta varies with gradients of hydrodynamic stress on coral reefs.

\section{Temporal variation in pumping}

Long-term measurements indicated that pumping activity was relatively constant over short temporal scales, but generally varied with the tides. A number of abiotic factors have been shown to effect sponge pumping activity, including turbidity, sedimentation, and temperature (Reiswig 1971, Riisgård et al. 1993). Environmental variables varied with the tides, but correlations between pumping by $X$. muta and environmental variables were not consistent between sponges. The common observance of asynchronous pumping activity among adjacent sponges further supports the conclusion that pumping is uncorrelated to the environment. It may be that pumping was not measured over a large enough range of environmental change to detect a significant relationship. Although it is possible for flow to be passively enhanced through the sponge by pressure gradients between the ostia and osculum generated by the Bernoulli effect and viscous entrainment (Vogel 1977, 1994), we did not find any evidence of a relationship between $\bar{w}$ and ambient currents. This is consistent with the calculations of Leys et al. (2011) that indicate hydraulic resistance would be too great for passive flow to occur in species such as $X$. muta that have thick walls and relatively long and narrow water canals (Weisz et al. 2008).

Near or total pumping cessation was also observed for approximately $21 \%$ of the sponges measured. Cessation was asynchronous and occurred over intervals ranging from 10 to $230 \mathrm{~min}$. Because no more than 1 cessation event was observed for a given sponge over measurement intervals of up to $2.5 \mathrm{~d}$, it was not possible to determine the periodicity of cessation. Pumping cessation is a common characteristic among sponges (Reiswig 1971, Vogel 1977, Pile et al. 1997) and typically occurs as a result of reduced choanocyte activity or contraction of excurrent canals at the spongocoel (Reiswig 1971). X. muta has a relatively incompressible skeletal architecture and no apparent contractions of individuals were observed, suggesting that pumping depression is due to a reduction in the activity of choanocytes. Patterns of cessation by $X$. muta are similar to patterns reported for the sponges $T$. crypta and $V$. reiswigi on Jamaican reefs (Reiswig 1971) and A. fistularis in Barbados (Reiswig 1981). For each species, cessation was asynchronous within the population, uncorrelated with changes in the environment, and intrinsically generated. Cessation occurred irregularly for individuals of $V$. reiswigi and lasted $42 \mathrm{~min}$ on average, but occurred at regular intervals of 9 to $21 \mathrm{~d}$ for individuals of T. crypta and lasted 1 to $5 \mathrm{~d}$. Pumping cessation was found for $13 \%$ of the population of $A$. fistularis surveyed (Reiswig 1981). The temporal variations in pumping reported here support Reiswig's (1971) hypothesis that thick-walled species working at high pressures are unable to maintain constant levels of pumping over time.

$X$. muta hosts a diversity of microbes, including some that perform a variety of anaerobic processes (e.g. denitrification) (Fiore et al. 2013). The significance of pumping depression and cessation to sponge and microbial symbiont biology is not well understood, and is clearly ripe for future research. Pumping activity is known to influence oxygen concentrations inside the sponge mesohyl, and anoxia can occur within $15 \mathrm{~min}$ of cessation (Hoffmann et al. 2008, Schläppy et al. 2010). Sponge tissue may switch from aerobic to anaerobic metabolism during cessation (Schläppy et al. 2010), however, the oxygen requirements of sponges may also be relatively low compared to other animals (Mills et al. 2014). Heterogeneity of oxygen concentrations within the mesohyl 
may influence the spatial and temporal structure of symbiotic microbial communities (Schläppy et al. 2010) and may explain the complexity of microbial processes found to occur in X. muta (Fiore et al. 2013).

Similar to other HMA species with variable pumping activities (Reiswig 1971, 1981), we hypothesize that pumping variation by $X$. muta is largely intrinsic over relatively constant environmental conditions; however, the adaptive significance of changes in pumping activity is not apparent. The energetic cost of pumping has long been thought to be low, at approximately $1 \%$ of total metabolism (Riisgård et al. 1993); however, recent work suggests that metabolic costs may actually be much higher (25 to $28 \%$ of total metabolism) than previous estimates (Hadas et al. 2008, Leys et al. 2011). If the energetic cost of pumping by $X$. muta is indeed high, then changes in pumping activity may be an adaptive response to the availability of picoplanktonic prey (Leys et al. 2011). Reiswig (1971) similarly hypothesized that reduced pumping by the sponge T. crypta at night was in response to a reduction of ambient currents and food availability. Pumping cessation by $X$. muta was found to typically occur at night; however, there was no clear relationship between ambient currents and illumination.

In conclusion, our results suggest a strong relationship between body size and morphology and sponge pumping rates. Excurrent velocity distributions of $X$. muta spanned the spectrum from plug to paraboliclike flow, and this variability highlights the careful characterization of excurrent flow profiles as a prerequisite to the study of sponge pumping rates. Further, we provide a novel hypothesis to explain how excurrent velocity distributions vary as a function of the partitioning of sponge biomass relative to the spongocoel. With the exception of sporadic periods of cessation, pumping activity was generally constant over time and uncorrelated with environmental conditions. Importantly, despite variations in sponge morphology and temporal variations in pumping activity, pumping rates were largely proportional to sponge biomass and can be predicted from simple measurements of sponge size that are regularly obtained by current coral reef monitoring efforts. Given its large biomass and abundance, populations of $X$. muta process large volumes of seawater and are predicted to have a dominant influence on water column processes on Caribbean coral reefs.

Acknowledgements. This study was funded by a grant from the National Oceanic and Atmospheric Administration's National Undersea Research Program at UNCW and by
National Science Foundation grants to C.M.F. (Ocean Sciences-0751753) and J.R.P. (Ocean Sciences-1029515, 05504658). We thank the staff of the NOAA's Aquarius Reef Base in Key Largo, Florida, and the crews of the R/Vs 'Walton Smith' and 'Seward Johnson' for logistical support. Assistance in the field was provided by Kristen Jabanoski, Tiffany Lewis, and Dr. Susanna López-Legentil. Dr. John Carroll provided thoughtful comments on previous versions of the manuscript. Research in the Florida Keys National Marine Sanctuary was performed under permit FKNMS2009-126-A1.

\section{LITERATURE CITED}

Bak RPM, Joenje M, de Jong I, Lambrechts DYM, Nieuwland G (1998) Bacterial suspension feeding by coral reef benthic organisms. Mar Ecol Prog Ser 175:285-288

Bell JJ, Davy SK, Jones T, Taylor MW, Webster NS (2013) Could some coral reefs become sponge reefs as our climate changes? Glob Change Biol 19:2613-2624

Bertin M, Callahan M (2008) Distribution, abundance and volume of Xestospongia muta at selected sites in the Florida Keys National Marine Sanctuary. Proc 11th Int Coral Reef Symp 2:686-690

Bidder GP (1923) The relation of the form of a sponge to its currents. Q J Microsc Sci 67:293-323

Box GEP, Jenkins GM, Reinsel GC (1994) Time series analysis. Prentice Hall, Upper Saddle River, NJ

Cloern J (1982) Does the benthos control phytoplankton biomass in south San Francisco Bay? Mar Ecol Prog Ser 9: 191-202

Colvard NB, Edmunds PJ (2011) Decadal-scale changes in abundance of non-scleractinian invertebrates on a Caribbean coral reef. J Exp Mar Biol Ecol 397:153-160

> de Goeij JM, van Oevelen D, Vermeij MJA, Osinga R, Middelburg JJ, de Goeij AFPM, Admiraal W (2013) Surviving in a marine desert: the sponge loop retains resources within coral reefs. Science 342:108-110

Díaz MC, Rützler K (2001) Sponges: an essential component of Caribbean coral reefs. Bull Mar Sci 69:535-546

- Finelli CM, Hart DD, Fonseca DM (1999a) Evaluating the spatial resolution of an acoustic Doppler velocimeter and the consequences for measuring near-bed flows. Limnol Oceanogr 44:1793-1801

Finelli CM, Pentcheff ND, Zimmer-Faust RK, Wethey DS (1999b) Odor transport in turbulent flows: constraints on animal navigation. Limnol Oceanogr 44:1056-1071

Fiore CL, Baker DM, Lesser MP (2013) Nitrogen biogeochemistry in the Caribbean sponge, Xestospongia muta: A source or sink of dissolved inorganic nitrogen? PLoS ONE 8:e72961

Gili JM, Coma R (1998) Benthic suspension feeders: their paramount role in littoral marine food webs. Trends Ecol Evol 13:316-321

> González-Rivero M, Yakob L, Mumby PJ (2011) The role of sponge competition on coral reef alternative steady states. Ecol Modell 222:1847-1853

> Hadas E, Ilan M, Shpigel M (2008) Oxygen consumption by a coral reef sponge. J Exp Biol 211:2185-2190

> Hoffmann F, Roy H, Bayer K, Hentschel U, Pfannkuchen M, Brümmer F, de Beer D (2008) Oxygen dynamics and transport in the Mediterranean sponge Aplysina aerophoba. Mar Biol 153:1257-1264

Hoegh-Guldberg O, Mumby PJ, Hooten AJ, Steneck RS and 
others (2007) Coral reefs under rapid climate change and ocean acidification. Science 318:1737-1742

> Larsen PS, Riisgård HU (1994) The sponge pump. J Theor Biol 168:53-63

Lewis TB, Finelli CM (2014) Epizoic zoanthids reduce pumping in two Caribbean vase sponges. Coral Reefs, doi:10.1007/s00338-014-1226-2

- Leys SP, Yahel G, Reidenbach MA, Tunnicliffe V, Shavit U, Reiswig HM (2011) The sponge pump: the role of current induced flow in the design of the sponge body plan. PLoS ONE 6:e27787

Loh TL, Pawlik JR (2014) Chemical defenses and resource trade-offs structure sponge communities on Caribbean coral reefs. Proc Natl Acad Sci USA 111:4151-4156

López-Legentil S, Pawlik JR (2009) Genetic structure of the Caribbean giant barrel sponge Xestospongia muta using the I3-M11 partition of COI. Coral Reefs 28:157-165

Maldonado M, Ribes M, van Duyl FC (2012) Nutrient fluxes through sponges: biology, budgets and ecological implications. In: Becerro MA, Uriz MJ, Maldonado M, Turon X (eds) Advances in sponge science: physiology, chemical and microbial diversity. Adv Mar Biol 62:113-182

> Massaro AJ, Weisz JB, Hill MS, Webster NS (2012) Behavioral and morphological changes caused by thermal stress in the Great Barrier Reef sponge Rhopaloeides odorabile. J Exp Mar Biol Ecol 416-417:55-60

> McArdle BH (1988) The structural relationship: regression in biology. Can J Zool 66:2329-2339

- McMurray SE, Blum JE, Pawlik JR (2008) Redwood of the reef: growth and age of the giant barrel sponge Xestospongia muta in the Florida Keys. Mar Biol 155:159-171

McMurray SE, Henkel TP, Pawlik JR (2010) Demographics of increasing populations of the giant barrel sponge Xestospongia muta in the Florida Keys. Ecology 91:560-570

McMurray SE, Blum JE, Leichter JJ, Pawlik JR (2011) Bleaching of the giant barrel sponge Xestospongia muta in the Florida Keys. Limnol Oceanogr 56:2243-2250

> Meroz-Fine E, Shefer S, Ilan M (2005) Changes in morphology and physiology of an East Mediterranean sponge in different habitats. Mar Biol 147:243-250

- Mills DB, Ward LM, Jones C, Sweeten B, Forth M, Treusch $\mathrm{AH}$, Canfield DE (2014) Oxygen requirements of the earliest animals. Proc Natl Acad Sci USA 111:4168-4172

Monismith SG, Davis KA, Shellenbarger GG, Hench JL and others (2010) Flow effects on benthic grazing on phytoplankton by a Caribbean reef. Limnol Oceanogr 55: 1881-1892

NOAA (National Oceanic and Atmospheric Administration) (2007) Florida Keys National Marine Sanctuary revised management plan. US Department of Commerce, NOAA, National Ocean Service, Silver Spring, MD

Officer CB, Smayda TJ, Mann R (1982) Benthic filter feeding: a natural eutrophication control. Mar Ecol Prog Ser 9:203-210

Palumbi SR (1986) How body plans limit acclimation: responses of a demosponge to wave force. Ecology 67 : 208-214

Peterson BJ, Chester CM, Jochem FJ, Fourqurean JW (2006) Potential role of sponge communities in controlling phytoplankton blooms in Florida Bay. Mar Ecol Prog Ser 328:93-103

Editorial responsibility: Josep-Maria Gili, Barcelona, Spain
Pile AJ, Patterson MR, Witman JD (1996) In situ grazing on plankton $<10 \mu \mathrm{m}$ by the boreal sponge Mycale lingua. Mar Ecol Prog Ser 141:95-102

Pile AJ, Patterson MR, Savarese M, Chernykh VI, Fialkov VA (1997) Trophic effects of sponge feeding within Lake Baikal's littoral zone. 2. Sponge abundance, diet, feeding efficiency, and carbon flux. Limnol Oceanogr 42:178-184

Reiswig HM (1971) In situ pumping activities of tropical Demospongiae. Mar Biol 9:38-50

> Reiswig HM (1974) Water transport, respiration and energetics of three tropical marine sponges. J Exp Mar Biol Ecol 14:231-249

Reiswig HM (1975) The aquiferous systems of three marine Demospongiae. J Morphol 145:493-502

- Reiswig HM (1981) Partial carbon and energy budgets of the bacteriosponge Verongia fistularis (Porifera: Demospongiae) in Barbados. Mar Ecol 2:273-293

> Riisgård HU, Thomassen S, Jakobsen H, Weeks JM, Larsen PS (1993) Suspension feeding in marine sponges Halichondria panicea and Haliclona urceolus: effects of temperature on filtration rate and energy cost of pumping. Mar Ecol Prog Ser 96:177-188

> Ritson-Williams R, Becerro MA, Paul VJ (2005) Spawning of the giant barrel sponge Xestospongia muta in Belize. Coral Reefs 24:160

> Ruzicka RA, Colella MA, Porter JW, Morrison JM and others (2013) Temporal changes in benthic assemblages on Florida Keys reefs 11 years after the 1997/1998 El Niño. Mar Ecol Prog Ser 489:125-141

Savarese M, Patterson MR, Chernykh VI, Fialkov VA (1997) Trophic effects of sponge feeding within Lake Baikal's littoral zone. 1. In situ pumping rates. Limnol Oceanogr 42:171-178

> Schläppy ML, Weber M, Mendola D, Hoffmann F, de Beer D (2010) Heterogeneous oxygenation resulting from active and passive flow in two Mediterranean sponges, Dysidea avara and Chondrosia reniformis. Limnol Oceanogr 55: 1289-1300

Southwell MW, Weisz JB, Martens CS, Lindquist N (2008) In situ fluxes of dissolved inorganic nitrogen from the sponge community on Conch Reef, Key Largo, Florida. Limnol Oceanogr 53:986-996

Vermeij GJ (1993) Evolution and escalation: an ecological history of life. Princeton University Press, Princeton, NJ

> Vogel S (1977) Current-induced flow through living sponges in nature. Proc Natl Acad Sci USA 74:2069-2071

Vogel S (1994) Life in moving fluids. Princeton University Press, Princeton, NJ

Warton DI, Wright IJ, Falster DS, Westoby M (2006) Bivariate line-fitting methods for allometry. Biol Rev Camb Philos Soc 81:259-291

Weisz JB, Lindquist N, Martens CS (2008) Do associated microbial abundances impact marine demosponge pumping rates and tissue densities? Oecologia 155:367-376

Yahel G, Post AF, Fabricius K, Marie D, Vaulot D, Genin A (1998) Phytoplankton distribution and grazing near coral reefs. Limnol Oceanogr 43:551-563

Yahel G, Sharp JH, Marie D, Häse C, Genin A (2003) In situ feeding and element removal in the symbiont-bearing sponge Theonella swinhoei: bulk DOC is the major source for carbon. Limnol Oceanogr 48:141-149

Submitted: July 10, 2014; Accepted: October 26, 2014

Proofs received from author(s): November 24, 2014 